\title{
Methodological Questions of Digital Teaching Material Development Made in the Subject of Mathematics
}

\author{
AndrÁs LÉnÁRD and Judit SzITÁNYI
}

Abstract. In the methodology of mathematics teaching, the selection and the manner of using applicable digital teaching materials appeared as a new element. As the number of digital teaching materials applicable in education is constantly increasing, their purposeful use is rarely discussed. In what areas digital teaching materials can be used in mathematics? What are the problems for which they could provide a solution? Shall we use them besides traditional solutions, or instead?

The authors of this article have had the opportunity to participate in projects aiming to develop digital learning materials on various occasions. During the implementation of the projects, they needed to make methodological compromises at various points.

In our article, we are seeking a more emphatic use of methodology belonging to digital teaching materials, drawing on the experiences of three implemented projects. Our aim is to draw the attention to the anomalies we found in the implementation of the projects, which must be taken into consideration in new developments already at the planning stage.

Key words and phrases: digital teaching materials, digital teaching unit, teaching material development, teaching development piloting, basic principles of methodology.

ZDM Subject Classification: U70, R20.

\section{Digital teaching materials in mathematics}

Digital teaching materials first appeared at the end of the 1980s. At the first stage, mostly the digital versions of traditional teaching materials dominated. This trend has prevailed ever since, and we can often see that certain 
digital teaching materials are the exact copies of tasks in traditional course books or workbooks, and their application is identical with the tasks in original, and mostly allows the quick and accurate checking of tasks during the lesson. At this early stage, hardware conditions did not allow the development of digital teaching materials which can spread widely, can be ran and exploit the opportunities offered by multimedia. Of course, the increased use of modern digital teaching materials, besides methodological aspects, also depends on the hardware environment available in the school.

At the second stage of teaching material development, the aspects, which regarded digital implementation as an extra feature became increasingly dominant. For many digital teaching material evaluation systems, the extra feature offered by the digital teaching material showing its necessity compared to/besides traditional teaching materials has become a priority requirement (Lénárd, 2014). Teachers have an increasing demand for useful digital teaching material. This demand ranged up to the base with thousands of digital teaching materials (Buda, 2017). For this reason, at this second stage, during the development of digital teaching materials the opportunities offered by multimedia were almost always used, from simple animations and figures to opportunities offered by augmented reality $(\mathrm{AR})$.

In an earlier study, we examined the content of the digital teaching material base commercially available in Hungary at the time. 47 teachers participated in the survey and they were asked during the teaching of which subjects they used digital devices. The analysis of the sample was started by comparing the relative frequency of subject categorization. The difficulty of the study was that certain teaching materials, due to their complex approach, cannot be categorized under one subject, or even content area. Here we tried to take every dominant subject and approach into consideration (Lénárd, 2013).

The dominance of the "man and nature" content area is attributed to the fact that this content area comprises the subjects of science, nature, biology, geography, physics, and chemistry. In the same study, we also performed an analysis of digital teaching materials according to teaching material type (Lénárd, 2013).

Mathematics has been an emphatic area in digital teaching material development from the beginning. When we examine the market of these teaching materials globally, we can tell that a high proportion of the digital teaching materials compiled processes teaching materials from the area of mathematics. 


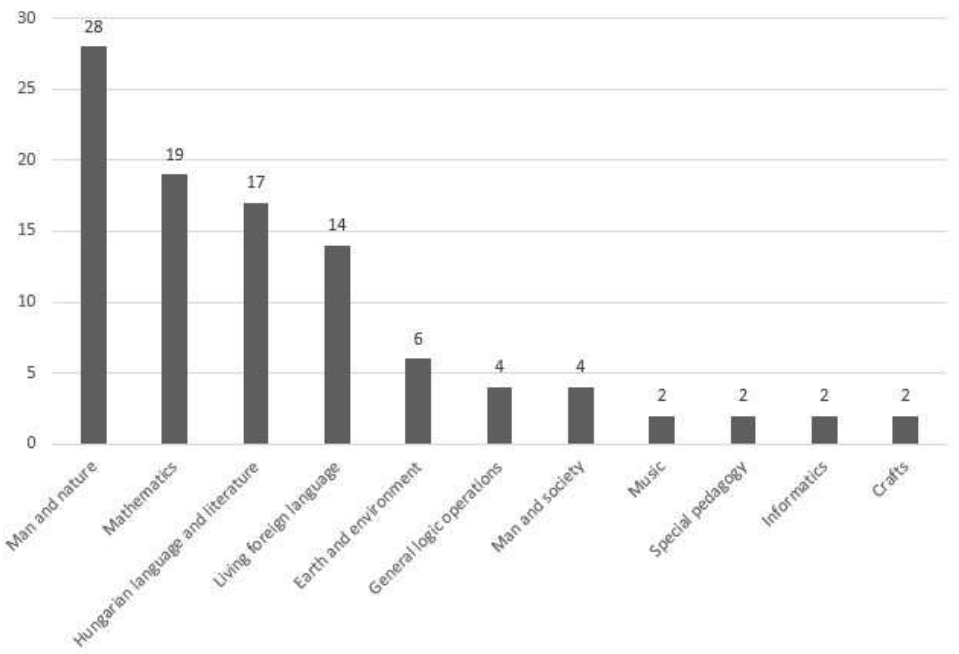

Figure 1. Distribution of commercially available digital teaching materials according to content area

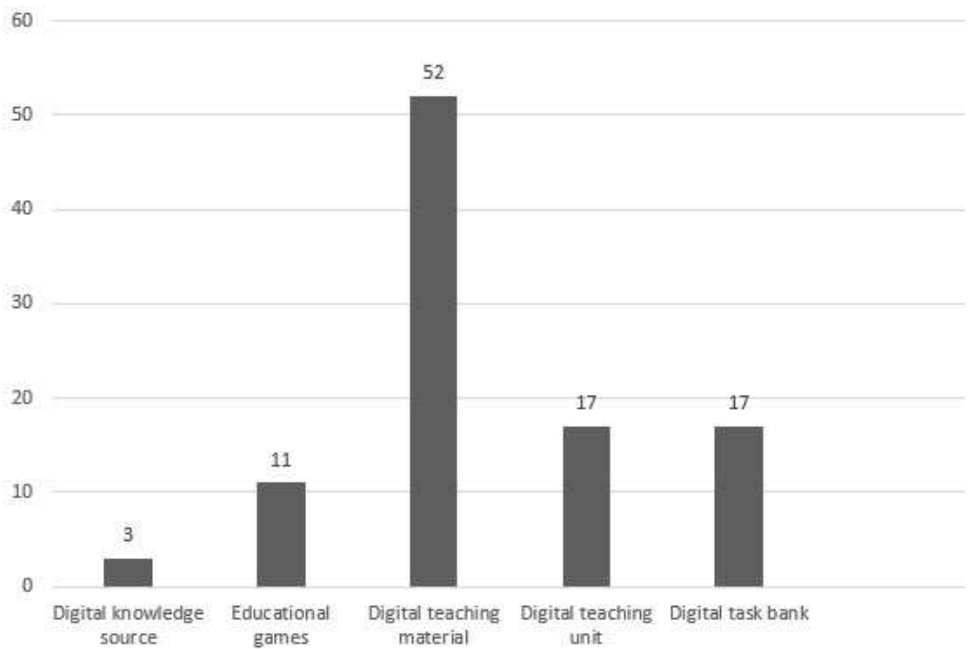

Figure 2. Distribution of the developed teaching material sample according to teaching material type 
This can be attributed to various reasons. On one hand, teaching materials and elements, the learning and practicing of which causes problems for students traditionally, come from the area of mathematics. On the other hand, certain task types and problems in mathematics can be algorhythmized well, thus programmers have to face a relatively simple coding process. Thirdly, certain topics in mathematics do not only provide an opportunity, but require a comprehensive, multimedia-based explanation and demonstration. Revising digital teaching materials in mathematics we have found that their content according to topic is not primarily made of topics which are difficult for students, but of solutions which can be easily implemented from a programmer's point of view.

For example: digital teaching materials practicing numeric counting seem to be over- represented compared to some other areas, e.g. geometry, combinatorics, or metric conversions. In another earlier study (Lénárd, 2016) a survey was carried out among pupils between 7-9 years of age about what topics they find difficult, and in what areas they would welcome digital teaching materials. In autumn 2015, at ELTE-TÓK, we made a survey with 26 ten-year-old pupils, where they were asked about their experience of the digital curricula. Following a written survey among pupils, it was outlined that they would need digital help mostly in the area of more complex word problems, metric conversions, geometry, and, surprisingly, in a minor, but often mentioned element of teaching, reading the analogue clock.

\section{Presentation of digital teaching material developments performed by the authors}

Between 2012 and 2017, we had the opportunity to participate in the development of several digital teaching materials in the subject of mathematics. The structure of the materials that were the result of this process was alike. In each case, you can choose the right curriculum on a collection page. You can search for classes, subjects, and specific material. The exercises contain a motivating description about the exercise itself for students and a description for teachers in which the methodology of application of the specific exercise and the areas to be developed are described. The user interface is the same for each exercise in terms of ease of use. 


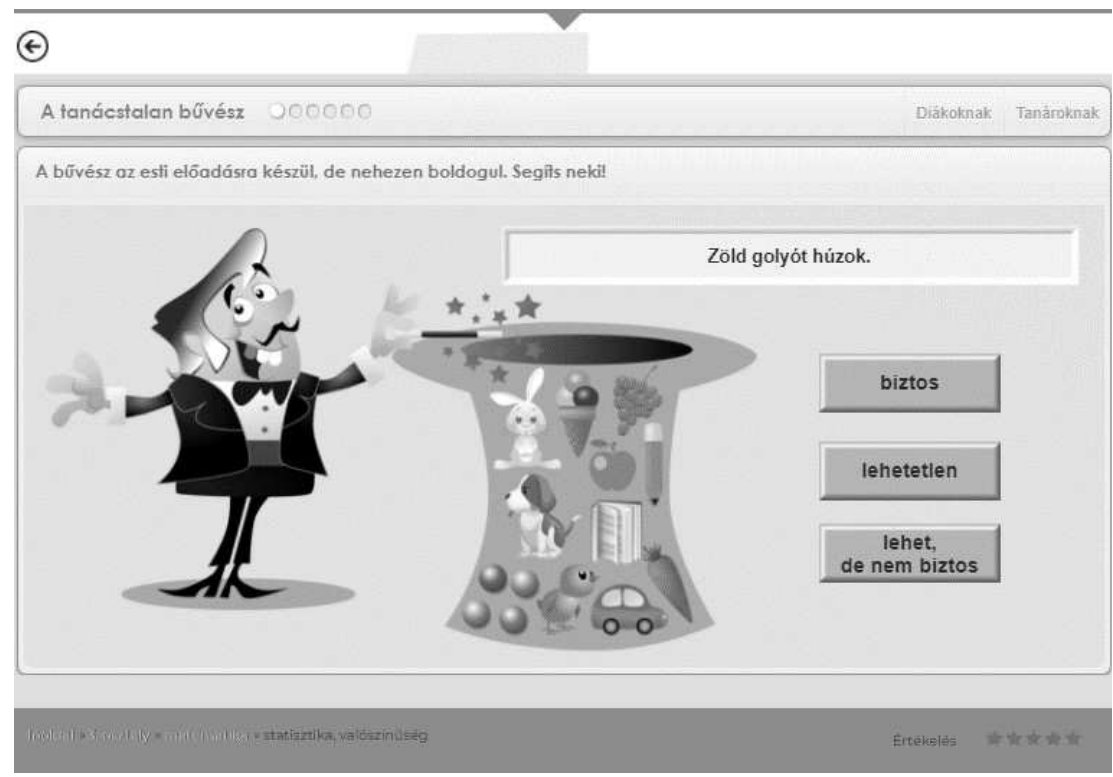

Figure 3. Task screen of a Smartbox

In the following, we would like to present these developments from the aspect what methodological problems we had to face during development, how we managed to tackle them, what were the paths of teaching material development we covered, and how they affected the development of our methodological culture then and in the future. We need to emphasize that we were involved in teaching material development as methodology experts, however, as we were not involved in the financing of the process, we could not influence every methodology aspect, and not every step of the development was driven by methodology aspects we established or found accurate, as on various instances they were overridden by economic or organizational aspects. The developments implemented were the following:

A: The Smartbox (Okosdoboz) digital teaching material system, which, with its 350 learning objects covered each topic of the complete framework curriculum in lower primary classes (between 6-10 years of age). In this case, the client's expressed wish was that a digital teaching material was to be developed proportionately for each and every curriculum unit, without taking into consideration how difficult the processing of the individual teaching unit is for the pupils. Initially, this teaching material system, besides a few free modules, was available 
commercially for children and schools. The individual teaching material elements were submitted to the accreditation procedure of the Hungarian Digital Teaching Material Assessment Committee (Digitális Tananyagminősítő Bizottság), which meant an analysis performed in three areas, by three independent experts, based on a set of criteria composed of 68 elements each. From 2015, the Hungarian government purchased this teaching material system, and made it available for everyone in its national digital teaching material database Smartportal (Okosportál). In this database, the digital teaching materials of other content areas are also available, e.g. Hungarian language and literature, science, music, etc., and a cross- curricular module for health education was also developed. Although there were general problems and experiences, in our present study we would like to focus on teaching materials development in the area of mathematics only.

B: Our second project, unlike the first project in which the digital teaching materials developed were intended for every pupil, was the development of a digital teaching material website explicitly for talent development. The website contained general, cognitive skill development and subject tasks too. The project was funded by the European Union, the professional supervision was provided by the Association of Hungarian Talent Developing Organizations (Magyar Tehetségsegítő Szervezetek Szövetsége, MATEHETSZ). In this development, our task was to develop digital teaching materials in mathematics covering the lower primary curriculum, with the intent of talent development. In this case, there was no need for exact age or class categorization, unlike the previous project, as here not the comprehensive teaching material range, but certain areas of talent development were in focus.

C: Our third project was implemented in the framework of the Geomatech project. The aim of the project was to develop the knowledge of students in science and mathematics. In mathematics, between 2014 and 20161200 teaching units were prepared with the relevant teachers' guidelines. The teaching units were developed with the software application GeoGebra, for 1-12. class students. An explicit goal was to cover the curriculum in a comprehensive manner and that it must be suitable both for talent development and catch-up purposes.

In the following, we will present methodology problems appearing at the individual stages of development and our attempts to overcome them. 


\section{Defining the topics and the teaching materials}

At the early stage of the projects, a difference in aspect emerged between methodology developers and the clients. In all the three projects, development progressed along curricular topics. The biggest concern in all three cases was whether a comprehensive covering of the curriculum is necessary. This was primarily essential for the client.

When the Smartbox was developed, an obvious requirement was that in each class each topic should be represented with the same emphasis. This was mainly due to the fact that the objective of the project was to create a comprehensive teaching material database covering the whole range of the curriculum and make it accessible for teachers, where each curriculum content had to appear. Missing content would have created the impression in users that the teaching material basis is not uniform or has gaps. Therefore it was a client requirement that in each area and unit we could present at least one digital teaching material. Of course, methodology developers did not consider this purposeful, and wanted to create more teaching material in the problematic areas. However, this was not possible due to financial limitations.

In the talent development project there was an opportunity to differentiate openly in a manner that problem solving and thinking structure developing tasks could be given more emphasis. We could use enrichment and skipping, thus we had neither age nor curriculum constraints.

In the Geomatech project, the methodology development team aimed to define the teaching material while preserving curriculum coverage in a manner that problematic questions were given more emphasis. Besides, we intended to address problems which overarch years. Thus there was an opportunity to apply familiar technical elements and thus repeat certain tasks in each year with some modification (e.g. by extending the number range). We feel the joint thinking of methodology developers was useful in this respect, facilitated the development of mathematical concepts from first grade to the maturity. Maybe this is the biggest added value of the Geomatech project.

However, in our experience comprehensive subject coverage required some compromises. Mathematics has topics where the planning of digital teaching units is difficult, and has little added value compared to the paper and pencil version. Energy spent on these developments could have been used elsewhere. We feel that concerning the selection of teaching materials and coverage it would be essential to rely on the expertise of methodology professionals. 


\section{The composition of the developer team}

In the first two projects the composition of the teams was similar. The methodology team consisted of renowned, practicing teachers and methodology experts, many of them working both in general and higher education, in many cases simultaneously. The developer team also had a member who had education and software development experience. His work was necessary because developers often proposed methodology solutions or task types which were excellent for subject pedagogy, however they could not be programmed on the given platform or could not be programmed cost-effectively. Another difficulty was that the ready teaching materials had to run on various platforms (PC, tablet, smartphone), therefore technical aspects often affected methodology aspects. E.g. small sized, detailed figures had to be avoided, data input by keyboard, or the use of animations requiring huge hardware resources. The team also comprised the representative of the client, who, on one hand supervised the meeting of deadlines, and on the other hand, cost-effectiveness. The coordinated work of the team members, scheduling and the coordination of the tasks was the responsibility of a project manager. Taking international experiences into consideration, in case of the talent development program, a few 9-10 year old pupils talented in some field of mathematics were added to the team. Our experiences obviously proved the correctness of this decision, however, we will expand on this aspect in detail later. Initially we can tell that these students worked as full right members of the team, their aspect, of course not lacking children's attitudes, was surprisingly professional.

The Geomatech project was implemented with the involvement of a high number of experts. Members of the methodology development team were methodology experts renowned in higher and general education. Their basic task was the creation of the specific teaching units, their possible implementation and creating teaching unit chains. As the materials were created for the Geogebra platform, it was indispensable that the opportunities and limitations of the platform should be taken into consideration already during planning. Members of the teaching material development team elaborated the methodology and technical descriptions, which helped the work of both student and teacher users. Besides, professional experts in programming, most of them with teaching experience, prepared the interactive material itself. Due to the limitations of the programming of Geogebra, in many cases the original ideas had to be given up. Especially in the case of materials for lower primary classes many compromises had to be made, as there 
the elaboration of moving figures and the richness of their details has a more significant role.

\section{Digital material development as a process}

For the development, we prepared a certain time chart and set template scenarios belonged to the individual digital teaching materials. These scenarios contained pedagogy, software ergonomics and design aspects in a complex manner. As the subject aspect was dominant, besides the year and age category, the curriculum topic and specific teaching material which was helped by the given digital teaching material also had to be given.

In the case of the talent development project, this was complemented by the presentation of those cognitive areas, which are especially developed by the given task. At the first stage, the scenario template is filled in by the methodology development teacher, however the individual cells, e.g. the cognitive areas are filled in by the methodology or psychologist expert.

The window containing the text of the instructions is an essential part of the template. Of these, in all the three projects two were used. One stored the instruction for the children, the other contained the methodology description for the teacher. We took special care when the instruction for children were worded, as this was of utmost importance for the task.

We also helped the selection of the teaching material by providing a third, brief, so-called collection page description. The primary goal of this description was to raise interest on the page containing the list of tasks. The categorization and the on-screen display of the high number of Geomatech teaching materials was a real challenge for the developer team. Finally, we agreed on creating a filtering system, in which our materials were displayed according to year and topic, and the chains could be also displayed.

A limitation, primarily in methodology descriptions was that due to the size of the working area, with special regard to tablets and phones, only a very brief description could be displayed, therefore we limited the maximum character number of the text boxes. Then the exact description of the tasks had to be done for the programmers, which was implemented purposefully along the questions "When is it happening? What/Who is it happening to? What is happening?". This part was prepared mostly for the programmer, therefore it was necessary that the wording should be done with everyday wording, not in pedagogical terminology, so that the operation can be understood by non-teacher programmers. 
In our experience, the biggest problem in development was the three types of aspects within a table and the change of wording for the three target groups (pupil, teacher, programmer). The highest number of corrections was not done in the tasks themselves, but in these texts. Of course, it also occurred that a non-obvious text for the programmer resulted in a program which did not work appropriately. As in the majority of tasks random number generalization could not be used, therefore as part of the scenario the creation of a block containing possible data and meanwhile a block containing the relevant solutions had to be created. The individual programs were uniformed in the manner that tasks were selected from these blocks randomly, to avoid that during work with a complete task any element of the block could repeat. Unfortunately, although we considered it desirable from a methodological point of view, the individual programs were not suitable (due to problems in size) to give tasks which get more and more difficult gradually, taking systematic progression into consideration. An essential part of the scenario was the cell containing score calculation, where the developer explained how many points a solution is worth for the first time and how many after help is provided. This was especially interesting when not only one element had to be analyzed, but several elements had to be arranged. The most important part of the scenario was the draft, which contained the outline of the display, indicating the position of the graphic elements, external features and their relative position compared to each other. Here developers only applied indicative graphic elements, as they had to be created by the graphic designers. Several authors prepared graphic elements by hand or attached them scanned or photographed to the scenario. Another methodological problem appeared at that stage, which affected the principle of variability. As a high number of tasks had to be programmed within a short time and the client wished to keep programming costs low, the tasks had to be standardized somehow. For this, so-called developer engines were created, which contained individual programming basic schemes. Methodology experts had to select from these engines and prepare the tasks, taking into consideration that tasks within one engine should appear varied for children. Such engines were for instance the engine selecting the elements of the given set, the engine examining the arrangement of data into a table, a match finding engine, the engine analysing the dragging of given elements to a given location, and the engine analysing the numbers appearing in the input field, etc. It was a great difficulty for programmers to create methodologically appropriate tasks which are also motivating for children and meet also the aforementioned 
expectations (Lénárd, 2016). We do not deny that at this stage, a conflict developed between methodologists and programmers, as programmers wished to cover as many task types with as few templates as it was possible, while methodology experts wished to create as varied, innovative and non-traditional tasks as it was possible. Compromises between the two groups had to be sought constantly, and this slowed down the development process to a great extent. In this, the expert, who was a methodology expert initially, but also had programming skills, had a key role.

As a high number of tasks was involved, at the second, talent development project an online platform called assembly line, developed by us, was used, where project participants could upload and modify data depending on their user access rights. Proof-readers marked the errors here which could be mended immediately, and programmers also asked their questions here, and the experiences of testing were also uploaded here. Each teaching program was an independent record, and the timestamp of the uploads and repairs was visible for the management, which on one hand helped the comprehension and coordination of the whole process in time, on the other hand it also inspired developers. However, developing such a platform is huge work, therefore it is only cost-effective when a great volume of digital teaching materials has to be developed. The platform accelerated the development process, as it consisted of independent digital teaching material bases, in operation besides the engines mentioned above there was some intent for uniformization, and the visual appearance of the different digital teaching materials showed some uniformity. This was necessary so that it can be managed by pupils easily, and thus there was no need for a detailed explanation or learning of the operation at each task. Meanwhile, this is obviously some kind of uniformization, and it has its negative aspects. It was quite difficult to create a balance between easy applicability and dullness.

During the development, proof-reading was performed in several stages and involved the following areas: the methodology proof-reader reviewed the given task on one hand from a didactic point of view, on the other hand taking into consideration the methodology of the given subject. It was necessary to create a set of evaluation criteria, which is specially digital teaching material focused, sufficiently detailed, but not too minuscule, as it had to be applied on a daily basis and quite quickly. Among assessment means available in professional literature, we selected the internationally popular and used check-list evaluation system prepared for professional evaluators (Tergan, 1998, Watts-Wojcik-Peterson-KarlanParette, 2008). As we managed to find proof-readers, who had had experience 
related to digital teaching materials, therefore these e-check-lists also contained software ergonomic criteria. The psychology proof-reader primarily examined the effect on the child's personality, and focused on effects generated with the individual cognitive areas. The proof-reader also took into consideration whether addressing the pupil and the description of the task for the pupil is in accordance with the given age. As a third stage, the programmers could also comment, however they had veto in the process when the proposed solution was not technically feasible. There were criteria which were outside the three aforementioned areas, however they were important, e.g. intellectual rights questions in case of graphic designs, the specific names of products and brands, they were supervised by the project manager.

After the compilation of the drafts of the tasks, there was a pre-testing stage, where the tasks were examined in their basic operation, without the final design elements.

\section{Experiences acquired during testing}

Basic deficiency issues appeared here and when the programmer misinterpreted the task. However, this occurred only a few times. Pre-testing was performed at several stages. First authors then the methodology proof-reader, and during the process, the project manager tested the application. Of course, before publication the programmers also performed internal testing. When the digital teaching material passed the pre-testing phase, it was finalized, with graphic elements, animations, and it was uploaded in a final version. The final testing phase was done with the involvement of further experts. Programmers tested on various platforms (PC, mobile, tablet) and on various operation systems as well. There were several, sometimes inexplicable errors, when the given digital teaching material worked a little differently ondifferent platforms or operation systems. The expertise of the programmers always provided a solution to these problems. Testing was also performed in a classroom environment, taking into consideration whether the interactive board can also be used appropriately as an input device. We have international experience concerning the involvement of students in the testing process (Squires-Preece, 1999, Robertson-Howells 2008, Hintastora-Mellar 2011, MacFarlane-Sim-Horton, 2011, Lénárd, 2016). This intent is practically as old as the digital teaching materials (Smith-Keep, 1986). The majority of the programs were tested also with students who highlighted problems which were often methodological in nature, which had not arisen before. Fortunately, no 
problem needing re-programming occurred which could not be mended with a simple or medium correction. This is due to the fact that the testing of most tasks by students was already performed by the authors already in the scenario stage, however, often not in a digital environment. It is extremely useful, and in our view, indispensable step in digital teaching material development to involve students in the testing process. This step cannot be replaced with multiple testing performed by adults. We often found that an instruction we considered obvious turned out to be problematic. When we analysed the reasons, we often found that the root cause of the problem was that students drew analogies between certain tasks they had solved many times in a non-digital environment, and based on an external feature, they set up an erroneous analogy. They did this in case of tasks where the authors' intent was innovation and breakup with traditional task types. At the last stage prior to the publication practicing teachers were involved in testing, who were not advanced digital teaching material users. The involvement of both professional and non-professional stakeholders is a widely used international practice (Squires-Preece, 1999, Lénárd, 2014). Their work was firstly helped by the aforementioned instructions prepared for teachers, and secondly, in both digital teaching material bases the curriculum objectives, topics and the database containing the key-words allocated to the individual digital teaching materials were prepared separately. In our experience, with these testers more problems occurred than in the case of students.

Interestingly, the source of the problems was almost the same. As for students: in our experience, teachers often identified the digital teaching material with a typical task already based on the name of the teaching material, or the first sentences of the teachers' instructions, or, most frequently, after viewing the graphic elements of the start screen, no matter in most cases it was not a typical task. In our experience, the misidentification was often attributed to the fact which mathematics coursebook series the teacher used, and what type of tasks and graphic implementations of the tasks dominated in the given coursebook series.

\section{The manifestation of methodological principles in digital teaching materials}

After the termination of the projects we can say that in all of the three cases many rich, varied and innovative teaching materials were developed. At present, it is only the authors' opinion, since for this purpose there is no survey 
yet. It may be the subject of further research whether after a couple of years of project closure these materials are still being used by teachers. However, for the teacher user it matters when and how these materials can be integrated into their everyday work. In all of our three projects in only a few cases methodology descriptions contain elements which present the manner of processing, which are important from the aspect of the building of the curriculum. For instance: what manipulative activities should precede the use of certain teaching materials? At what stage of the learning phase it is worth giving children the teaching unit? Does the given teaching unit serve deepening of knowledge or does it prepare a concept? What help we can provide the children when we see they have no sufficient mathematic experience to use the teaching material?... Answering these questions would be of great help for teachers, even if we know that a certain teaching unit can be used in different manners.

In the case of all the three projects the developer team well defined the methodology principles they wished to follow. However, these do not appear on the platforms or only partly. During testing, it was not an important criterion to check whether the teaching units are in accordance with the methodological principles provisioned. Maybe the embedding of the teaching material in the pedagogical system was the criterion, where our projects performed the weakest. Thus the teacher faces difficulties when they try to find the most suitable side for their own methodological ideas.

The selection of the teaching unit is made even more difficult by the fact that in many cases the title or the thumbnail on the screen cannot provide all the information which might be necessary for the teacher. Thus the teacher has to open and interpret the possible teaching units one by one, which is quite timeconsuming. Therefore we consider important the more exact positioning of the teaching units in the curriculum.

\section{Summary}

We can summarize the methodological approaches of our digital teaching material developing experiences in the three big projects in the following:

(1) An essential, however in practice often not feasible aspect shall be the priority of the methodological approach. There is a strict limit for compromise in financial vs. methodological issues. The principle must be at all price an approach, which is methodologically and didactically accurate, varied, and 
takes into consideration the peculiarities of the given age. If we need sacrifices, we should sacrifice the amount of tasks, and not the variety of methodology.

(2) It is crucial to harmonize programming technique aspects and methodological implementation, therefore it is worth including an expert in the team dedicated to this task. We should try to, in spite of the difficulties, find an expert, who, besides being up-to-date in methodological and scientific issues, is also familiar with the process of digital teaching material development, criteria, and quality assurance.

(3) When the content of the digital teaching materials is designed, it is vital to involve the given age group. In our experience, it is quite surprising how deep and thorough the consideration of students as young as 8-10 years of age is; we were astonished that "digital sugar coating", as referred by Prensky, i.e. preferring useless, methodologically non-grounded design elements, was not relevant (Prensky, 2001). Already at the first stage it is important to map what arises for the given age group as a mathematical problem. It is essential that developers should not give in to temptation, i.e. should not elaborate the problems as digital teaching units, which are easy to implement technically or where the necessary graphic elements or task types are already available, but those, where digital implementation is an extra helping the learning process. Therefore it is worth using animations, unusual graphic designs or simulation, present the given problem through the tools of the digital world affecting many senses, and allowing multiple approaches.

(4) It is also crucial that not only the digital teaching material itself, but the complete development process must be planned, however teachers or pedagogy experts are rarely suitable for this task, thus it is worth relying on the work of an expert familiar with process planning, even if it means an extra cost. As a part of this process it is also extremely important to elaborate a set of evaluation criteria, by which the quality assurance of the individual stages of the development process can be realized.

(5) In a next project it would be worth considering the integrability of digital teaching materials along the aspects of the development of students and the curriculum. On one hand, in the teaching units more specific recommendations must be made for the manner of processing, on the other hand a curriculum recommendation or guidelines must be prepared, which contains the existing digital teaching materials, detailing the manner of use. Further teaching material development should be done in areas where there is a deficiency. 


\section{References}

[1] A. Buda, Az IKT és oktatás. Együtt vagy egymás ellen?, Belvedere Meridionale Kiadó, Szeged, 2017, 32-34.

[2] A. Lénárd, A digitális tananyagfejlesztés új útjai: szoftverfejlesztés a tanulók bevonásával, in: Innovatív módszerek a pedagógiai-pszichológiai gyakorlatban Ukrajna európai integrációjának tükrében, (E. Berghauer-Olasz, I. Greba, É. Hutterer, K. Pallay, eds.), Kálvin Nyomda, Ukrajna, Beregszász, 2016, 237-244.

[3] A. Lénárd, A multimédiás digitális tananyagok alkalmazásának és minősitésének didaktikai szempontrendszere a 6-12 éves korosztály esetében, $\mathrm{PhD}$ értekezés, ELTE Neveléstudományi Doktori Iskola, Budapest, 2013.

[4] A. Lénárd, A digitális tananyagok nyelvi és képi világának problémái a tananyagfejlesztés során, in: XXI. századi kompetenciák: Kisgyermekek és kisiskolások verbális és literális tevékenységeinek kompetenciaalapú megközelítése a KÉP-korszakban, ELTE Tanító- és Óvóképző Kar, Budapest, 2016, 14-15.

[5] A. Lénárd, Kísérlet a digitális tananyag-értékelés hazai és nemzetközi gyakorlatának áttekintésére egy komplex rendszer alkalmazásával, in: XVI. Oktatás-Informatikai Konferencia Tanulmánykötet, (J. Ollé, ed.), ELTE PPK Neveléstudományi Intézet, Budapest, 2016, 375-392.

[6] S. Macfarlane, G. Sim, M. Horton, Assessing usability and fun in educational software, 2005

http://dl.acm.org/citation.cfm?doid=1109540.1109554. Last download: 20.08.2017.

[7] A. McDougall, D. Squires, A Critic al Examination of the Checklist Approach in Software, Selection Journal of Educational Computing Research 12, no. 3 (1995), 263-274.

[8] M. Prensky, Digital Natives, Digital Immigrants. Part 1-2. 2001/10., On the Horizon, NCB University Press 9, no. 5 (2001).

[9] J. Robertson, C. Howells, Computer game design: Opportunities for successful learning, computer, Computers \& Education 50, no. 2, February (2008), 559-578.

[10] G. Sim, S. Macfarlane, J. Read, All work and no play: Measuring fun, usability, and learning in software for children, 2006

http://www. sciencedirect.com/science/article/pii/S0360131505001594.

Last download: 20.08.2017.

[11] D. Smith, R. Keep, Children's opinions of educational software, Educational Research 28, no. 2 (2006), 83-88.

[12] D. Squires, J. Preece, Predicting quality in educational software: Evaluating for learning, usability and the synergy between them, Interacting with Computers 11, no. 5 (1999), 467-483.

[13] S. O. Tergan, Checklists for the Evaluation of Educational Software: Critical Review and Prospects, Innovations in Education \& Training International 35, no. 1 (1999), 9-20. 
[14] E. H. Watts, B. W. Wojcik, G. R. Peterson-Karlan, H. Parette, P.: Educational software evaluation form. Appendix A., The Gardner School (2003-04). Eight ways of being smart., 2006

http://www.gardnerschool.org/eightwaysofsmart.htm. Last download: 20.08.2017.

Web sites:

[15] GEOMATECH PORTÁL http://tananyag.geomatech.hu/. Last download: 20.08.2017.

[16] OKOSDOBOZ DIGITÁLIS FELADATBANK http://www.okosdoboz.hu/. Last download: 20.08.2017.

[17] CSIBÉSZTÚRA TEHETSÉGSEGÍTŐ PORTÁL http://csibesztura.hu/ . Last download: 20.08.2017.



(Received October, 2017) 